\title{
MOLECULAR DETECTION OF ANAPLASMA SPP. IN CATTLE OF TALESH COUNTY, NORTH OF IRAN
}

\author{
S. SALEHI-GUILANDEH ${ }^{1}$, Z. SADEGHI-DEHKORDI ${ }^{1}$, \\ A. SADEGHI-NASAB ${ }^{2} \&$ A. YOUSEFI ${ }^{3}$
}

${ }^{1}$ Department of Parasitology, Faculty of Paraveterinary Medicine, Bu-Ali Sina University, Hamedan, Iran; ${ }^{2}$ Department of Clinical Sciences; Faculty of Paraveterinary Medicine, Bu-Ali Sina University, Hamedan, Iran; ${ }^{3}$ Young Researchers and Elites club, Science and Research Branch, Islamic Azad University, Tehran, Iran

\section{Summary}

Salehi-Guilandeh, S., Z. Sadeghi-Dehkordi, A. Sadeghi-Nasab \& A. Yousefi, 2019. Molecular detection of Anaplasma spp. in cattle of Talesh County, North of Iran. Bulg. J. Vet. Med., 22, No 4, 457-465.

Anaplasmosis is generally caused by intraerythrocytic rickettsia of Anaplasma genus and transmitted biologically and mechanically. The current study was designed to determine the prevalence of Anaplasma spp. in cattle in Talesh; one of the rainy Iranian counties in Gilan province, Iran. From May to November 2015, one hundred and fifty blood samples of cattle were collected from different regions in Talesh. DNA was extracted from blood samples and subsequently, 16S rRNA and MSP4 genes were analysed by Nested-PCR method for differentiation of Anaplasma spp. The results showed that $40.66 \%$ of blood samples were positive for Anaplasma spp. and that $24.66 \%, 35.33 \%$, $9.33 \%$ and $12 \%$ of positive samples were infected with A. phagocytophilum, A. bovis, A. marginale and $A$. centrale respectively. Statistical analysis by Chi-square test did not show any significant relationship between the presence of Anaplasma species and variables sex, age and tick infestation $(\mathrm{P}>0.05)$. The 4 species of Anaplasma reported in this study are of potential importance for animal and public health.

Key words: Anaplasma, cattle, tick-borne, Talesh, Iran

\section{INTRODUCTION}

Anaplasmosis is generally caused by intraerythrocytic rickettsia of genus Anaplasma (Dumler et al., 2001). This bacteria is transmitted biologically by ticks and mechanically by Stomoxys and Tabanus or blood contaminated instruments (Kocan et al., 2010). Anaplasmosis is important in two respects: first, economic losses from reduced milk production, abortion and weight loss iinduced by Anaplasma ovis, Anaplasma marginale, Anaplasma centrale and Anaplasma bovis (Rymaszewska \& Grenda, 2008). Second comes the zoonotic importance of Ana- 
plasma phagocytophilum (HGA) which causes a variety of clinical syndromes from mild in healthy subjects to severe in immunocompromised or elderly people (Murray et al., 2005; Robinson et al., 2009).

Anaplasmosis generally occurs in subtropical and tropical areas but as a result of global warming, the distribution of disease and particularly anaplasmosis may be expected to change, due to the location changes of biological vectors (Jonsson \& Reid, 2000; Kocan et al., 2010). Hence the present survey was conducted to determine the prevalence of Anaplasma spp. in cattle in Talesh county, one of the rainy Iranian counties in Gilan province, Iran.

\section{MATERIALS AND METHODS}

\section{Study area}

Talesh is located on the southwestern coast of the Caspian Sea (37 $21^{\circ} 54^{\prime \prime} \mathrm{N}$, $\left.50^{\circ} 5^{\prime} 34^{\prime \prime} \mathrm{E}\right)$. Talesh County covers an area of 2,373 square kilometers area of Gilan Province. The annual average precipitation and temperature are $1,360 \mathrm{~mm}$ and $24.9^{\circ} \mathrm{C}$ respectively (Fig. 1).

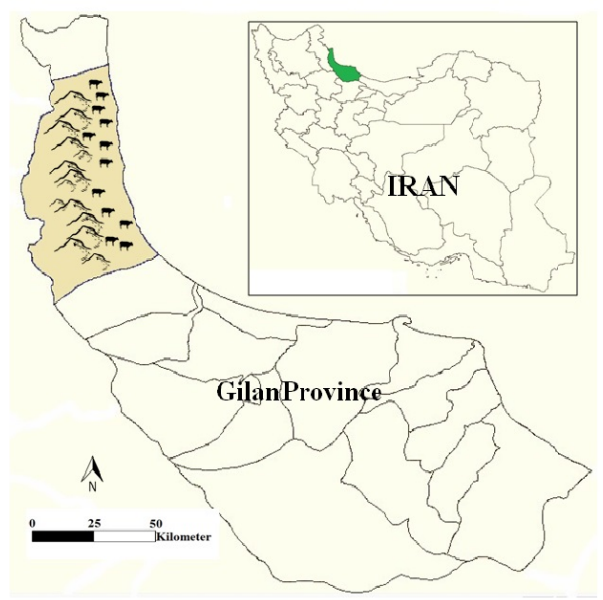

Fig. 1. Map of studied areas, sampling regions in Talesh county (Gilan province, Iran).

\section{Sampling}

From May to November 2015, one hundred and fifty blood samples (each $2 \mathrm{~mL}$ ) were collected from the jugular vein of cattle ( 75 male; 75 female) in a sterile test tube containing $1 \mathrm{~mL} 96 \%$ ethanol from twelve different farms in the different regions of Talesh county.

All applicable international, national, and institutional guidelines for the care and use of animals were followed.

\section{DNA extraction}

DNA of blood samples was extracted using the DNA extraction minikit (YTA, Iran, Cat No: FABGK001) following the manufacturer protocol. Twenty $\mu \mathrm{L}$ Proteinase $\mathrm{K}$ and $200 \mu \mathrm{L}$ BG Buffer were added to $50 \mathrm{mg}$ of fixed blood sample, mixed thoroughly by vortexing and incubated for $15 \mathrm{~min}$ at $60{ }^{\circ} \mathrm{C}$. In the next step, $200 \mu \mathrm{L}$ ethanol $(96 \%)$ was added to the sample and mixed thoroughly by vortexing for $30 \mathrm{~s}$. The complete volume of solution was transferred into the BG column and was centrifuged at 8,000 rpm for 1 min. Then BG column was placed to a new collection tube. The BG column was immediately washed twice with $500 \mu \mathrm{L}$ and $750 \mu \mathrm{L}$, respectively $\mathrm{W} 1$ Buffer, centrifuged at $14000 \mathrm{rpm}$ and then the flowthrough was discarded. Subsequently 100 $\mu l$ of Elution Buffer was added to the membrane center of BG column and centrifuged for $2 \mathrm{~min}$ at $14000 \mathrm{rpm}$ to elute the DNA. The extracted DNA was analysed in agarose gel and also by spectrophotometry. The ratio of $\mathrm{OD}_{260}$ to $\mathrm{OD}_{280}$ and the amount of extracted DNA and its purity were measured.

\section{PCR of $16 S$ rRNA gene}

The Anaplasma spp. 16S rRNA gene was amplified by PCR in $50 \mu \mathrm{L}$ reaction volume, containing $10 \mathrm{mM}$ Tris- $\mathrm{HCl}$ 
Table 1. Sequence details of primers used in PCR and Nested-PCR of 16S rRNA and MSP4 genes

\begin{tabular}{|c|c|c|c|c|c|}
\hline Primer & Genbank No. & $\begin{array}{l}\text { Nucleotide sequences } \\
5^{\prime} \rightarrow 3^{\prime}\end{array}$ & $\begin{array}{l}\text { Nucleotide } \\
\text { positions }\end{array}$ & $\begin{array}{l}\text { Target } \\
\text { organism }\end{array}$ & $\begin{array}{l}\mathrm{PCR} \\
\text { product }\end{array}$ \\
\hline P1 & \multirow[t]{2}{*}{$\begin{array}{l}\text { M60313 } \\
(16 \mathrm{~S} \text { rRNA) }\end{array}$} & $\begin{array}{l}\text { AGAGTTTGATCCTGGCT } \\
\text { CAG }\end{array}$ & $1-20$ & \multirow[t]{2}{*}{$\begin{array}{l}\text { Anaplasma } \\
\text { spp. }\end{array}$} & \multirow[t]{2}{*}{781 bp } \\
\hline $\mathrm{P} 2$ & & $\begin{array}{l}\text { AGCACTCATCGTTTACA } \\
\text { GCG }\end{array}$ & $796-815$ & & \\
\hline P6 & \multirow[t]{2}{*}{$\begin{array}{l}\text { M73224 } \\
(16 \text { S rRNA) }\end{array}$} & $\begin{array}{l}\text { CTTTATAGCTTGCTATA } \\
\text { AAGAA }\end{array}$ & $69-90$ & \multirow[t]{2}{*}{$\begin{array}{l}\text { A. phago- } \\
\text { cytophilum }\end{array}$} & \multirow[t]{2}{*}{509 bp } \\
\hline P4 & & $\begin{array}{l}\text { GTTAAGCCCTGGTATTT } \\
\text { CAC }\end{array}$ & $575-594$ & & \\
\hline P7 & \multirow[t]{2}{*}{$\begin{array}{l}\text { Af283007 } \\
(16 \mathrm{~S} \text { rRNA) }\end{array}$} & $\begin{array}{l}\text { CAAATCTGTAGCTTGCT } \\
\text { ACGGA }\end{array}$ & $65-86$ & \multirow[t]{2}{*}{ A.centrale } & \multirow[t]{2}{*}{$513 \mathrm{bp}$} \\
\hline P4 & & $\begin{array}{l}\text { GTTAAGCCCTGGTATTT } \\
\text { CAC }\end{array}$ & $575-594$ & & \\
\hline P8 & \multirow[t]{2}{*}{$\begin{array}{l}\text { AB196475 } \\
\text { (16S rRNA) }\end{array}$} & $\begin{array}{l}\text { CTCGTAGCTTGCTATGA } \\
\text { GAAC }\end{array}$ & $68-89$ & \multirow[t]{2}{*}{ A.bovis } & \multirow[t]{2}{*}{509 bp } \\
\hline P4 & & $\begin{array}{l}\text { GTTAAGCCCTGGTATTT } \\
\text { CAC }\end{array}$ & $575-594$ & & \\
\hline M-OM F & \multirow[t]{2}{*}{$\begin{array}{l}\text { HM640938.1 } \\
\text { (MSP4) }\end{array}$} & $\begin{array}{l}\text { GGGAGCTCCTATGAATT } \\
\text { ACAGAGAATTGTTTAC }\end{array}$ & $1-33$ & \multirow[t]{2}{*}{$\begin{array}{l}\text { A.margina- } \\
\text { le/A. ovis }\end{array}$} & \multirow[t]{2}{*}{867 bp } \\
\hline M-OM R & & $\begin{array}{l}\text { CCGGATCCTTAGCTGA } \\
\text { ACAGGAATCTTGC }\end{array}$ & $839-867$ & & \\
\hline $\begin{array}{l}\text { M-MAF } \\
\text { M-MAR }\end{array}$ & $\begin{array}{l}\text { HM640938.1 } \\
\text { (MSP4) }\end{array}$ & $\begin{array}{l}\text { CTGAAGGGGGAGTAAT } \\
\text { GGG } \\
\text { GGTAATAGCTGCCAGA } \\
\text { GATTCC }\end{array}$ & $\begin{array}{l}113-131 \\
435-456\end{array}$ & $\begin{array}{l}\text { A. margi- } \\
\text { nale }\end{array}$ & $344 \mathrm{bp}$ \\
\hline
\end{tabular}

(pH 9.0), $30 \mathrm{mM} \mathrm{KCl,} 1.5 \mathrm{~mm} \mathrm{MgCl}_{2}$, $250 \mu \mathrm{m}$ of each dNTP, $0.5 \mu \mathrm{m}$ of each forward and reverse primers (P1/P2) (Table 1), 1.0 U Taq polymerase (Cinnagen, Iran) and $2 \mu \mathrm{L}$ of DNA in automated thermocycler (Astec, Germany) for 37 cycles. Following an initial denaturation step of 5 min at $95{ }^{\circ} \mathrm{C}$, each cycle consisted of a denaturing step of $45 \mathrm{~s}$ at $94{ }^{\circ} \mathrm{C}$, annealing for $45 \mathrm{~s}$ at $58^{\circ} \mathrm{C}$ and extension for $45 \mathrm{~s}$ at $72{ }^{\circ} \mathrm{C}$ and was completed with the final extension step for $5 \mathrm{~min}$. The PCR amplicons $(781 \mathrm{bp})$ were analysed in $1.5 \%$ agarose gel stained with ethidium bromide and UV condition (Fig.2A).

\section{Nested-PCR of 16S rRNA gene}

This technique was performed for detection of different Anaplasma species in 25 $\mu \mathrm{L}$ reaction volume, containing $10 \mathrm{mM}$ Tris- $\mathrm{HCl}$ (PH 9.0), $30 \mathrm{mM} \mathrm{KCl}, 1.5 \mathrm{mM}$ $\mathrm{MgCl}_{2}, 250 \mu \mathrm{m}$ of each dNTP, $0.5 \mu \mathrm{m}$ of each forward and reverse primers specific for each species (Table 1), $1.0 \mathrm{U}$ Taq polymerase (Cinnagen, Iran) and $1 \mu \mathrm{L}$ (diluted 1:200) of PCR products $(781 \mathrm{bp})$ in automated thermocycler (Astec, Germany) for 35 cycles. Following an initial denaturation step of $5 \mathrm{~min}$ at $95{ }^{\circ} \mathrm{C}$, each cycle consisted of a denaturing step of $45 \mathrm{~s}$ at $94{ }^{\circ} \mathrm{C}$, annealing for $45 \mathrm{~s}$ at $57^{\circ} \mathrm{C}$, extension step of $45 \mathrm{~s}$ at $72{ }^{\circ} \mathrm{C}$ and a final extension step for $5 \mathrm{~min}$ at $72{ }^{\circ} \mathrm{C}$. The PCR amplicons (A. bovis: 509 bp; Fig. 2B, A. phagocytophilum: 509 bp; Fig. 3A), A. centrale: 513bp; Fig. 3B) were analysed in $1.5 \%$ agarose gel stained with ethidium bromide. 
Molecular detection of Anaplasma spp. in cattle of Talesh County, North of Iran

\section{PCR of MSP4 gene}

For primers design limitations that existed in the 16s rRNA gene for differentiation between $A$. ovis and A. marginale, we used the MSP4 gene. This technique in first step was performed for detection of A. marginale/ A. ovis in $25 \mu \mathrm{L}$ reaction volume, containing $10 \mathrm{mM}$ Tris- $\mathrm{HCl}(\mathrm{PH}$ 9.0), $30 \mathrm{mM} \mathrm{KCl}, 1.5 \mathrm{mM} \mathrm{MgCl}_{2}, 250$ $\mu \mathrm{m}$ of each dNTP, $0.5 \mu \mathrm{m}$ of each forward and reverse primers specific for $A$. mar-

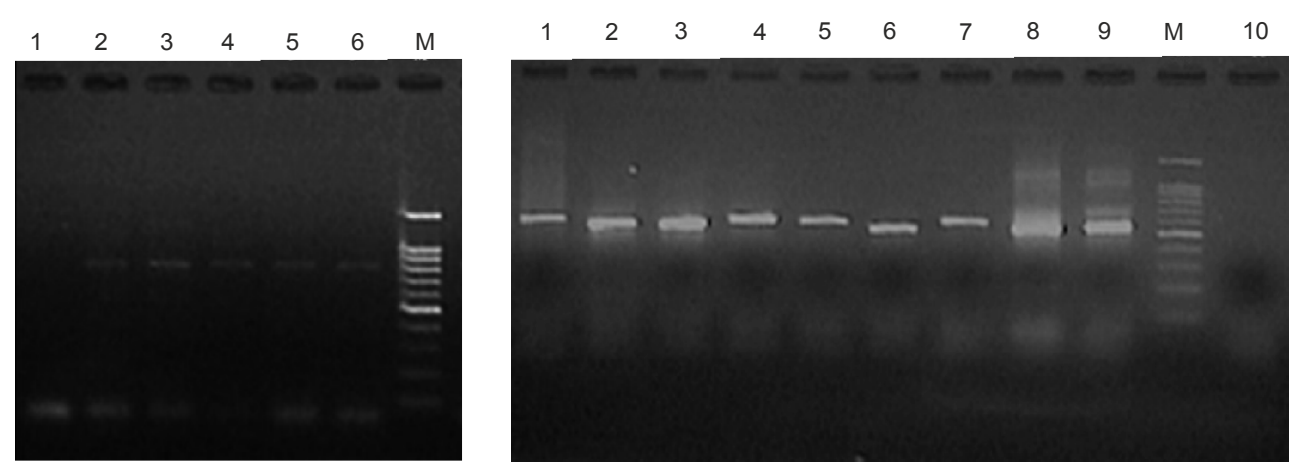

Fig. 2. A. PCR products of Anaplasma spp. $16 \mathrm{~S}$ rRNA gene (781 bp), lane 1: negative control, lane 2: positive control, lanes 3 to 6: Anaplasma spp., M: $100 \mathrm{bp}$ DNA ladder B. Nested-PCR products of $A$. bovis in 16S rRNA gene (509bp), Lanes 1 to 8: A. bovis, lane 9: positive control; lane 10: negative control.
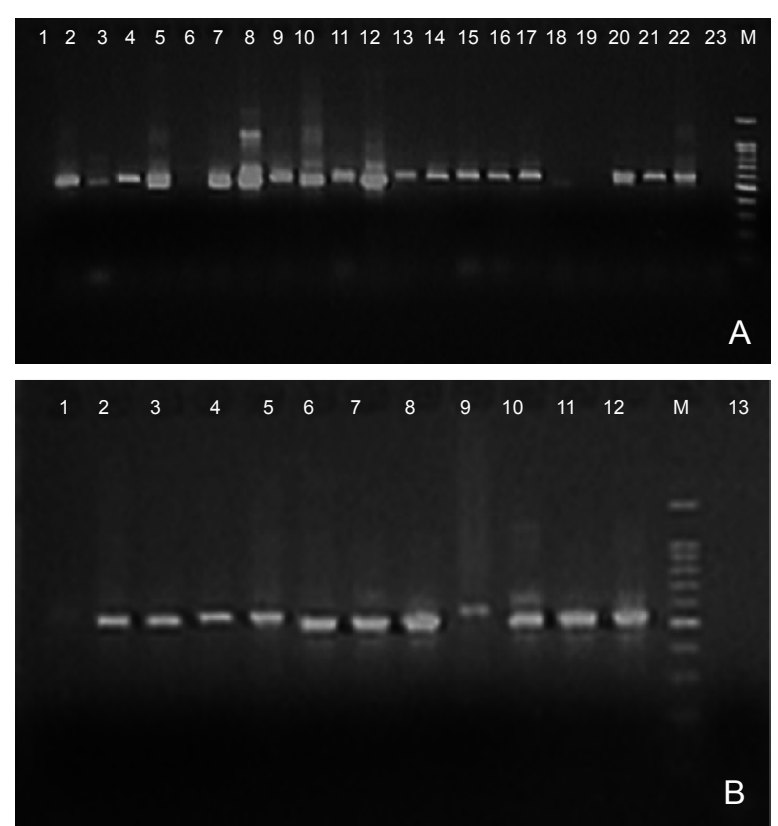

Fig. 3. A. Nested-PCR products of A. phagocytophilum in 16 srRNA gene (509 bp),

lanes 2-5, 7-17, 20 and 21: A. phagocytophilum, lane 22: positive control, lane 23: negative control,

M: $100 \mathrm{bp}$ DNA ladder. B. Nested-PCR products of $A$. centrale in 16 srRNA gene (513 bp), lanes 2-11: A. centrale, lane 12: positive control, lane 13: negative control. 

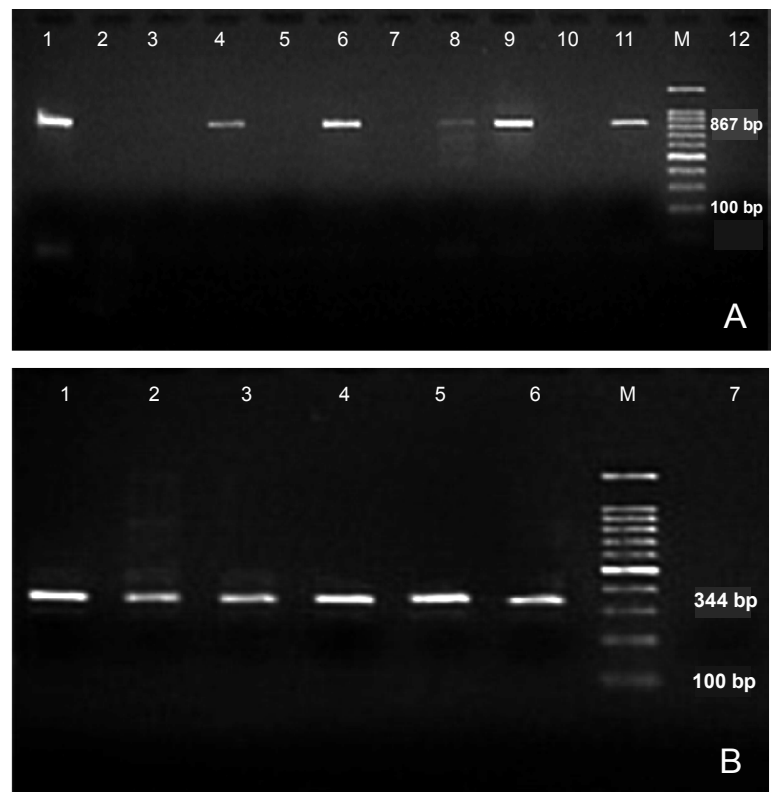

Fig. 4. A. PCR products ( $867 \mathrm{bp}$ ) of A. marginale/A. ovis in MSP4 gene, lanes 1, 4, 6, 8 and 9: A. marginale, lane 11: positive control, lane 12: negative control, M: $100 \mathrm{bp}$ DNA ladder.

B: Nested PCR products (344 bp) of A. marginale in MSP4 gene, lanes 1 to 5: A. marginale, lane 6: positive control, lane 7: negative control, M: 100 bp DNA ladder.

ginale/A. ovis (Table 1), 1.0 U Taq polymerase (Cinnagen, Iran) and $2 \mu \mathrm{L}$ DNA in automated thermocycler (Astec, Germany) for 32 cycles. Following an initial denaturation step of $5 \mathrm{~min}$ at $95{ }^{\circ} \mathrm{C}$, each cycle consisted of a denaturing step of $30 \mathrm{~s}$ at $94{ }^{\circ} \mathrm{C}$, annealing for $30 \mathrm{~s}$ at $60{ }^{\circ} \mathrm{C}$ and extension step of $30 \mathrm{~s}$ at $68{ }^{\circ} \mathrm{C}$ and with the final extension step for $5 \mathrm{~min}$ at $68^{\circ} \mathrm{C}$. The PCR amplicons of $A$. marginale/ A. ovis: 867 bp (Fig. 4A) were analysed in $1.5 \%$ agarose gel stained with ethidium bromide.

\section{Nested-PCR of MSP4 gene}

This technique was performed for differentiation between $A$. ovis and A. marginale by Nested PCR in $25 \mu \mathrm{L}$ reaction volume, containing $10 \mathrm{mM}$ Tris- $\mathrm{HCl}(\mathrm{PH}$ 9.0), $30 \mathrm{mM} \mathrm{KCl}, 1.5 \mathrm{mM} \mathrm{MgCl}_{2}, 250$ $\mu \mathrm{m}$ of each dNTP, $0.5 \mu \mathrm{m}$ of each forward and reverse primers specific for $A$. marginale (Table 1), 1.0 U Taq polymerase (Cinnagen, Iran) and $1 \mu \mathrm{L}$ (diluted 1:200) of PCR products ( $867 \mathrm{bp}$ ) in automated thermocycler (Astec, Germany) for 35 cycles. Following an initial denaturation step of $5 \mathrm{~min}$ at $95{ }^{\circ} \mathrm{C}$, each cycle consisted of a denaturing step of $15 \mathrm{~s}$ at $94{ }^{\circ} \mathrm{C}$, annealing for $20 \mathrm{~s}$ at $58^{\circ} \mathrm{C}$, extension step of $15 \mathrm{~s}$ at $72{ }^{\circ} \mathrm{C}$ and a final extension for $5 \mathrm{~min}$ at $72^{\circ} \mathrm{C}$. The PCR amplicons of $A$. marginale: 344 bp (Fig.4 B) were analysed in $1.5 \%$ agarose gel stained with ethidium bromide.

\section{Positive controls}

All positive control samples used in this study were previously sequenced and was provided by the Department of Veterinary Parasitology, University of Tehran. 


\section{Statistical analysis}

The chi-square test was used to analyse the statistical significance between Anaplasma species presence and variables such as sex, age and tick infestion at $95 \%$ confidence level. using SPSS v21.0 statistical software.

\section{RESULTS}

PCR and Nested PCR assessment of DNA samples based on 16S rRNA and MSP4 genes showed that $40.66 \%(61 / 150)$ of blood samples were positive for Anaplasma spp. In particular, 24.66\% (37/150), $\quad 35.33 \% \quad(53 / 150), \quad 9.33 \%$ $(14 / 150)$ and $12 \%(18 / 150)$ of positive samples were infected with $A$. phagocytophilum, A. bovis, A. marginale and $A$. centrale respectively.

All positive samples of Anaplasma species except 1 sample of $A$. centrale, 3 samples of $A$. phagocytophilum and 22 samples of $A$. bovis had mixed infection with other Anaplasma species. Also, A. marginale was the only species who was always seen with other species (Table 2).

Statistical analysis performed using the Chi-square test to assess the relationship between the presence of Anaplasma species and sex, age and tick infestation of cattle did not show any statistically significant relationships $(\mathrm{P}>0.05)$.

\section{DISCUSSION}

The 16S rRNA gene was selected for PCR because of high copy numbers in orde $5 r$ to increase the accuracy of detection of Anaplasma genome in infected animals with low parasitaemia. Since the nucleotides of the hypervariable $\mathrm{V} 1$ region of the $16 \mathrm{~s}$ rRNA gene in $A$. marginale and $A$. ovis are not significantly different (they differ only in two base pairs), the design of a specific primer for any of them is impossible, and therefore, the MSP4 gene was used to differentiate between $A$. marginale and $A$. ovis species (Noaman, 2013).

Numerous researches have been conducted on anaplasmosis distribution among ruminants in Iran and in fact, studies in cattle anaplasmosis have been limited in some areas (Razmi et al., 2006; Ahmadi-Hamedani et al., 2009; Noaman \& Shayan, 2009; 2012; Jalali et al., 2013; Hosseini-Vasoukolaei et al., 2014; Noaman \& Bastani, 2016; Yousefi et al., 2017a,b; Yousefi, 2018). Based on available information no studies have been carried out to investigate the prevalence of A. marginale, A.centrale, A. phagocytophilum and A.bovis in ruminants from Gilan province.

Our results on $A$. phagocytophilum $(24.66 \%)$ demonstrated a high prevalence compared to previous studies in Iran, as reported by Bashiribod et al. (2004) among I. ricinus $(5.1 \%)$, by Noaman \& Shayan (2009) in cattle (1.33\%) and Yousefi et al. (2017a,b) in sheep and goats $(1.08 \%)$. However, the prevalence of A. phagocytophilum in some reports on cattle from other countries as China (35\%; Yang et al., 2013) and Turkey (24.8\%; Aktas \& Özübek, 2015) were similar to our results. Our results showed $35.33 \%$ prevalence of $A$. bovis which is higher than the results reported by Noaman \& Shayan (2012) from cattle, HosseiniVasoukolaei et al. (2014) from Boophilus annulatus and sheep $-2.66 \%, 25 \%$ and $1.54 \%$ respectively. The results of the present study about $A$. centrale prevalence $(12 \%)$ are different, when compared to the low prevalence $(1.33 \%)$ found out in the study conducted in Esfahan (Noaman, 2013). On the other hand, contrary to pre- 
S. Salehi-Guilandeh, Z. Sadeghi-Dehkordi, A. Sadeghi-Nasab \& A. Yousefi

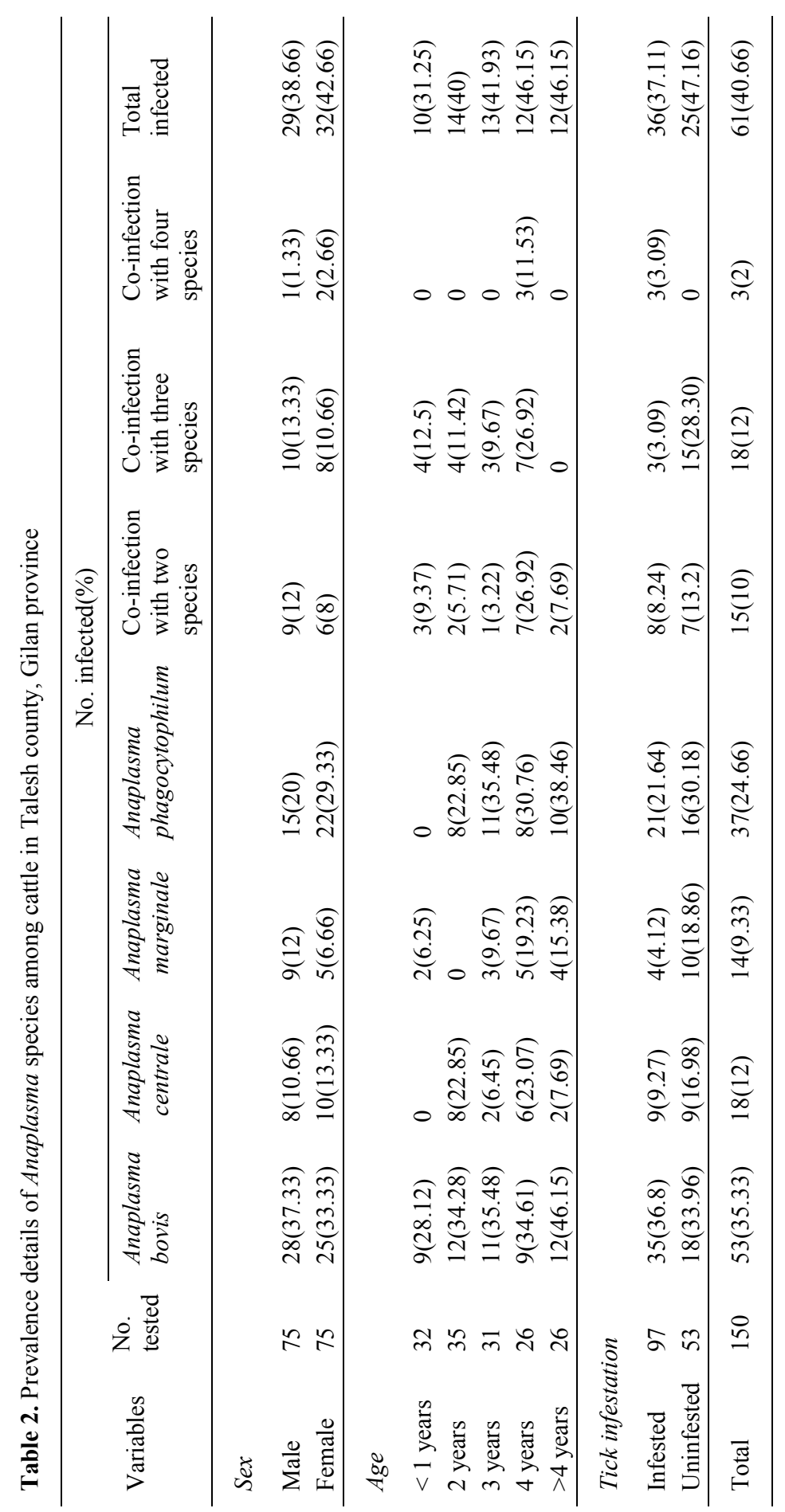

BJVM, 22, No 4 
vious studies, the prevalence of $A$. marginale in this study was low $(9.33 \%)$.

In discussing the high frequency of Anaplasma species evidenced by our results compared to those of others, it must be said that Iran has a diverse climate in different areas and that of Gilan province can be classified as humid subtropical climate (Skerman \& Hillard, 1966). Due to the fact that the climate type will determine the type of insect fauna such as ticks, the presence of these vectors and their populations can affect the spread of different tick-borne diseases especially the prevalence of Anaplasma species. Further studies are required in diffrent areas to ascertain our knowledge and to verify Anaplasma species isolates, especially zoonotic species such as $A$. phagocytophilum in other animals, human and Anaplasma vectors in Iran.

\section{ACKNOWLEDGEMENTS}

This paper is a part of the M.Sc thesis of the senior author and financially supported by $\mathrm{Bu}-$ Ali Sina University, Hamedan, Iran. The authors would like to thank Dr. Vahid Noaman for his advice in during study.

\section{REFERENCES}

Ahmadi-Hamedani, M., Z. Khaki, S. Rahbari, B. Kazemi \& M. Bandehpour, 2009. Molecular identification of anaplasmosis in goats using a new PCR-RFLP method. Iranian Journal of Veterinary Research, 10, 367-372.

Aktas, M., \& S. Özübek, 2015. Bovine anaplasmosis in Turkey: First laboratory confirmed clinical cases caused by Anaplasma phagocytophilum. Veterinary Microbiology, 178, 246-251.

Bashiribod, H., B. Kazemi, G. Eslami, Sh. Bigdeli, M. Bandehpour, N. Rahbarian \& Z. Ramezani, 2004. First molecular detec- tion of Anaplasma phagocytophilum in Ixodes ricinus ticks in Iran. Journal of Medical Science, 4, 282-286.

Dumler, J. S., A. F. Barbe, C. P. Bekker, G. A. Dasch, G. H. Palmer, S. C. Ray, Y. Rikihisa \& F. R. Rurangirwa, 2001. Reorganization of genera in the families Rickettsiaceae and Anaplasmataceae in the order Rickettsiales: Unification of some species of Ehrlichia with Anaplasma, Cowdria with Ehrlichia and Ehrlichia with Neorickettsia, descriptions of six new species combinations and designation of Ehrlichia equi and 'HGE agent' as subjective synonyms of Ehrlichia phagocytophila. International Journal of Systematic and Evolutionary Microbiology, 51, 2145-2165.

Hosseini-Vasoukolaei, N., M. A. Oshaghi, P. Shayan, H. Vatandoost, F. Babamahmoudi, M. R. Yaghoobi-Ershadi, Z. Telmadarraiy \& F. Mohtarami, 2014. Anaplasma Infection in ticks, livestock and human in Ghaemshahr, Mazandaran province, Iran. Iranian Journal of Arthropod Borne Disease, 8, 204-211.

Jalali, S. M., Z. Khaki, B. Kazemi, M. Bandehpour, S. Rahbari, M. Razi Jalali \& S. P. Yasini, 2013. Molecular detection and identification of Anaplasma species in sheep from Ahvaz, Iran. Iranian Journal of Veterinary Research, 14, 50-56.

Jonsson, N. N. \& S. W. J. Reid, 2000. Global climate change and vector borne diseases. The Veterinary Journal, 160, 87-89.

Kocan, K. M., J. de la Fuente, E. F. Blouin, J. F. Coetzee \& S. A. Ewing, 2010. The natural history of Anaplasma marginale. Veterinary Parasitology, 167, 95-107.

Murray, P. R., K. S. Rosenthal \& M. A. Pfaller. 2005. Medical Microbiology, $5^{\text {nd }}$ edn, Elsevier Mosby, United States.

Noaman, V. \& D. Bastani, 2016. Molecular study on infection rates of Anaplasma ovis and Anaplasma marginale in sheep and cattle in West-Azerbaijan province, Iran. Veterinary Research Forum, 7, 163 167. 
Noaman, V. \& P. Shayan, 2009. Molecular detection of Anaplasma phagocytophilum in carrier cattle of Iran-first documented report. Iranian Journal of Microbiology, 1, 37-42.

Noaman, V. \& P. Shayan, 2012. Molecular detection of Anaplasma bovis in cattle from central part of Iran. Veterinary Research Forum, 1, 117-122.

Noaman, V., 2013. Report of Anaplasma centrale (Amori strain) in cattle in Iran. Veterinary Journal (Pajouhesh \& Sazandegi), 98, 26-29.

Razmi, G. R. \& K. Dastjerdi, H. Hosseini, A. Naghibi, F. Barati, \& M. R. Aslani, 2006. An epidemiological study on Anaplasma infection in cattle, sheep and goats in Mashhad suburb, Khorasan province, Iran. Annals of the New York Academy of Sciences, 1078, 479-481.

Robinson, M. T., S. E. Shaw \& E. R. Morgan, 2009. Anaplasma phagocytophilum infection in a multi-species deer community in the New Forest, England. European Journal of Wildlife Research, 55, 439-442.

Rymaszewska, A., \& S. Grenda, 2008. Bacteria of the genus Anaplasma - characteristics of Anaplasma and their vectors: A review. Veterinarni Medicina, 53, 573-584.

Skerman, K. D. \& J. J. Hillard, 1966. A Handbook for Studies of Helminth Parasites of Ruminants. Iran Unit United Nations Development Programme/ Special Fund Handbook No.2. Near East Animal Health Institutes.

Yang, J., Z. Liu, G. Guan, Q. Liu, Y. Li, Z. Chen, M. Ma, A. Liu, Q. Ren, J. Luo, \& H. Yin, 2013. Prevalence of Anaplasma phagocytophilum in ruminants, rodents and ticks in Gansu, north-western China. Jounal of Medical Microbiology, 62, 254258.

Yousefi, A., S. Rahbari, P. Shayan, Z. Sadeghi-Dehkordi \& A. Bahomar, 2017. Molecular detection of Anaplasma marginale and Anaplasma ovis in sheep and goat in west highland pasture of Iran. Asian Pacific Journal of Tropical Biomedicine, 7, 455-459.

Yousefi, A., S. Rahbari, P. Shayan, Z. Sadeghi-Dehkordi \& A. Bahomar, 2017. Molecular evidence of Anaplasma phagocytophilum: An emerging tick-borne pathogen in domesticated small ruminant of Iran; first report. Comparative Clinical Pathology, 26, 637-642.

Yousefi, A., 2018. Phylogenetic analysis of Anaplasma marginale and Anaplasma ovis isolated from small ruminant based on MSP4 gene in western regions of Iran. Comparative Clinical Pathology, 27, 1-5.

Paper received 12.01.2018; accepted for publication 16.03.2018

\section{Correspondence:}

Ali Yousefi

Young Researchers and Elites Club, Science and Research Branch, Islamic Azad University, Tehran, Iran Tell:+989183075573

email: Aliusafi@yahoo.com 